\title{
ON A SPECIMEN OF NOEGGERATHIOPSIS FROM THE LOWER COAL MEASURES OF NEW SOUTH WALES.
}

\author{
By A. B. WaLkOM, D.Se.
}

(Plate xxv.)

The object of the present short note is to place on record a remarkably fine specimen of Noeggerathiopsis, from between the two splits of the Greta Seam in the Lower Coal Measures of New South Wales.

There is no need here to give any historical account of the genus in Australia, for the late R. Etheridge, Jr., has gone into this very fully in a recent paper (Geol. Mag., July, 1918, pp. 289-293). He there described four elusters of leaves, bringing the number of speeimens found in Australia, showing the radiate arrangement of the leaves, up to seven. The specimen deseribed here also shows this arrangement and is far larger than any previously described; it brings the number up to eight. It was exhibited by Mr. C. A. Sussmilch before the Geology Section of the Royal Society of N.S.W. (Journal, liv., 1920, p. xxxiv.) Associated with the Noeggerathiopsis, on the same specimen, are several fragments of leaves of Glossopteris. Plate xxv. is from a photograph of the specimen.

The specimen shows the remains of portions of some 13 or 14 leaves attached to a central stem which is from 1.5 to $2 \mathrm{~cm}$. in diameter. The leaves are spread out on a fine-grained grey shale, and arranged in a radiate manner. They are all incomplete, none of them showing the nature of the apex; the majority of them, however, show a considerable portion, while a few only show a few $\mathrm{cm}$. of the basal part. The largest portion of a leaf has a length of 17-18 $\mathrm{em}$. and gradually becomes broader from the base outwards; it is about $1 \mathrm{~cm}$. broad where it joins the stem, and $3.5 \mathrm{~cm}$. wide at about $17 \mathrm{~cm}$. from the stem. The specimen shows quite clearly that the arrangement of the leaves is not verticillate; this is also of course obvious from the fact that there are about 14 leaves present, each being about $1 \mathrm{~cm}$. wide at the base, and attached to a stem whose circumference is apparently not more than about $7 \mathrm{~cm}$. Close examination indicates that the arrangement is probably spiral, though one cannot determine the phyllotaxy.

The venation is rather coarse, the veins slightly divergent and bifureating from time to time. There are about 14 veins per $\mathrm{cm}$. on an average, but there is no sign of any finer venation between the coarser veins, such as has been observed in species of Cordaites. It may be noted, however, that quite frequently the veins have the appearance of being arranged in pairs. It was because of the absence of these interstitial veins together with the fact that the stomata appeared to be less regularly arranged that Zeiller retained the name Noeggerathiopsis in preference to Cordaites for these leaves.

Interstitial veins have however since been found on specimens of Noeggerathiopsis from India and South America (see Seward, Fossil Plants, iii., p. 243), 
so that in the absence of specimens having the euticle well preserved, it is impossible to distinguish between the genera Cordaites and Noeggerathiopsis. In view of Seward's account (Fossil Plants, iii., p. 243-4) of investigations by the late Miss Ruth Holden, which indicate differences between the Gondwana Land Noeggerathiopsis and the European Cordaites, we prefer for the present to retain the former name for the Australian examples.

In his paper, quoted above, Etheridge did not discuss the specific identity or otherwise of the Australian specimens of Noeggerathiopsis.

As far as I know there is very little at present on which one could separate the leaves specifically, and it seems best to refer them all to N. Hislopi (Bunb.). In none of the specimens so far deseribed have any anatomical details been made out, and the only eharacters on which separation has been based are variations in the shape and venation-the former not at all reliable and the latter hardly any more so in this ease. Species deseribed as $N$. spathulata Dana, N. media (Dana), from the Upper Coal Measures and $N$. prisca Feistmantel, from the Lower Coal Measures do not appear to be sufficiently distinct to be separated from the widely-known $N$. Hislopi.

In deseribing a specimen from the Upper Coal Neasures of New South Wales as N. Goepperti (Schmal.) Arber (Quart. Jour. Geol. Soc., lxviii., 1902. p. 20) says-"As regards the identity of N. Hislopi (Bunb.), the representative of this genus in India, South Africa, South America and also probably in Australia with $N$. Goepperti, I have not been able to arrive at a definite conclusion. There is a great similarity of habit and detail between them."

Though specimens showing clusters of leaves are so rare, examples of single leaves are not uncommon in association with the Glossopteris Flora in Australia, both in the Lower and Upper Coal Measures. No well-authenticated specimens are known from newer rocks in Australia.

Attention may here be drawn to a specimen recently assigned to this genus by Shirley (Q'land Naturalist, ii., 1920, p. 82). He describes a fragment from the Ipswich Beds (Upper Triassic) at Albion, near Brisbane, Queensland, as $n$ new species, N. Tryoni. I had an opportunity of examining the specimen (of which there is no figure and no record of the location of the type), ${ }^{*}$ and $m y$ notes, made at the time, show that I regarded it as a fragmentary piece of a large Ginkgo or Baiera, showing two segments of the leaf close together with a narrow band of matrix between them; this narrow band of matrix is what has been deseribed as the midrib of $N$. Tryoni.

All the specimens, previously deseribed, showing the radiate arrangement of the leaves of Noeggerathiopsis were obtained from the Upper Coal Measures, some from Neweastle, the others from the Illawarra District. The specimen described above, which was obtained from the Stanford Merthyr Colliery, is the first example from the Lower (Greta) Coal Measures; it was forwarded to Mr. Sussmileh by Mr. H. M. Williams, Superintendent of the Stanford Merthyr Colliery, and is now in the collection of the Technological Museum, Newcastle.

I am indebted to Mr. Sussmilch for the opportunity of deseribing the specimen.

EXPLANATION OF PLATE XXV.

Specimen of Noeggerathiopsis Hislopi (Bunb.) showing radiate arrangement of the leaves. $\left(x \frac{3}{5}\right)$.

- In a recent letter, Mr. H. A. Longman, Director of the Queensland Museum, mentions that this type has been presented to the Museum. 


\section{$2 \mathrm{BHL}$ Biodiversity Heritage Library}

Walkom, A.

B.

I

. 1921. "On a specimen of Noeggerathiopsis from the Lower Coal Measures of New South Wales." Proceedings of the Linnean Society of New South Wales 46, 374-375. https://doi.org/10.5962/bhl.part.14026.

View This Item Online: https://www.biodiversitylibrary.org/item/23930

DOI: https://doi.org/10.5962/bhl.part.14026

Permalink: https://www.biodiversitylibrary.org/partpdf/14026

\section{Holding Institution}

MBLWHOI Library

Sponsored by

MBLWHOI Library

\section{Copyright \& Reuse}

Copyright Status: NOT_IN_COPYRIGHT

This document was created from content at the Biodiversity Heritage Library, the world's largest open access digital library for biodiversity literature and archives. Visit BHL at https://www.biodiversitylibrary.org. 